See discussions, stats, and author profiles for this publication at: https://www.researchgate.net/publication/271199875

\title{
Sea cucumber Holothuria forskali, a new resource for aquaculture? Reproductive biology and nutraceutical approach
}

Article in Aquaculture Research · January 2015

Dol: 10.1111/are.12683

CITATIONS

27

8 authors, including:

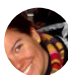

Rita Santos

i3S/IBMC

9 PUBLICATIONS 51 CITATIONS

SEE PROFILE

(6) Susete Filipa Gonçalves Pinteus

Instituto Politécnico de Leiria

72 PUBLICATIONS 742 CITATIONS

SEE PROFILE

\section{READS}

1,282

Some of the authors of this publication are also working on these related projects:

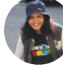

Eliana Dias

Instituto Politécnico de Leiria

6 PUBLICATIONS 50 CITATIONS

SEE PROFILE

Joana Silva

MARE | Marine and Environmental Sciences Centre, Polytechnic Institute of Leiria

59 PUBLICATIONS 569 CITATIONS

SEE PROFILE

Project $\quad$ "Marine Natural Products as Anticancer Agents" - Special issue View project

Project CROSS-ATLANTIC - CReating Opportunities from Seaweed Sulfated polysaccharides for Application in Therapeutics View project 


\title{
Sea cucumber Holothuria forskali, a new resource for aquaculture? Reproductive biology and nutraceutical approach
}

\author{
Rita Santos, Simaura Dias, Susete Pinteus, Joana Silva, Celso Alves, Carla Tecelão, Rui Pedrosa \\ \& Ana Pombo \\ Marine Resources Research Group (GIRM), Polytechnic Institute of Leiria, Peniche, Portugal
}

Correspondence: A Pombo, School of Tourism and Maritime Technology - Polytechnic Institute of Leiria. Santuário de Nossa Senhora dos Remédios, Peniche 2520-641, Portugal. E-mail: ana.pombo@ipleiria.pt

\begin{abstract}
Sea cucumbers are highly marketable as a food product due to their nutritional value. Also, it has been suggested that sea cucumbers possess a wide range of bioactive compounds that can be used in the pharmaceutical industry. In this study, the reproductive biology of Holothuria forskali was performed by evaluating the gonadosomatic index (GI) and histological analyses of the gonadal tubules. The biotechnological potential was assessed through the evaluation of the antioxidant, antimicrobial and antitumor potential. Finally, the fatty acid profile was also evaluated. These three subjects were chosen to increase the interest and to focus the economic potential of this species rearing, predicting that it can be sold in Europe or export to Asia to be used for human consumption or for the pharmaceutical industry. The GI and the histological analysis of the gonadal tubules revealed that the range from February to March corresponds to the peak of gonads maturation. Furthermore, the methanolic fraction revealed the highest antimicrobial potential against Candida albicans with an $\mathrm{IC}_{50}$ of $233.2 \mathrm{mg} \mathrm{mL}^{-1}$. Also, this fraction presented the highest cytotoxic and anti-proliferative activities through the method for measuring cell proliferation method in both cell lines, with an $\mathrm{IC}_{50}$ of 238.2 and $396.0 \mathrm{mg} \mathrm{mL}^{-1}$ for MCF-7 cells respectively and 260.3 and $218.7 \mathrm{mg} \mathrm{mL}^{-1}$ for HepG-2 cells respectively. Regarding the fatty acid profile, the total fat content was $4.83 \%$ and the highest values were obtained for palmitic acid (9.96\%), stearic acid (11.23\%), eicosapentaenoic acid (10.49\%) and arachidonic acid (20.36\%).
\end{abstract}

Keywords: sea cucumber, antimicrobial activity, antitumor activity, HepG-2 and MCF-7 cell lines, marine natural compounds, fatty acid profile

\section{Introduction}

Holothurians, known worldwide as sea cucumbers, are worm-like soft-bodied echinoderms that can be found in almost every marine environment of the world (Ghobadyan, Morovvati, Ghazvineh \& Tavassolpour 2012; Yu, Qi, Hu, Liu \& Huang 2012).

For centuries, sea cucumbers have been a popular luxury food item in Asian seafood markets (Conand 2001; Ferdouse 2004; Raison 2008), where most of the products are traded and sold in the dried form, beche-de-mer. This has led to an increasing overfishing of the natural stocks. Furthermore, nowadays, to continuous supply the high demand from the Asian markets, new non-target species from the north hemisphere are being fished and traded (Battaglene 1999; Conand 2004; Sicuro \& Levine 2011; Nelson, MacDonald \& Robison 2012).

Aquaculture has been proving to be a promising source of sea cucumbers input in Asian markets, but due to the lack of knowledge about some species biology, ecology and reproduction, this profitable industry has not been yet introduced for a large number of species (Chen 2004; Ivy, Azari \& Giraspy 2006). In addition, recent scientific evidence supporting their importance as nutraceuticals and functional food has attracted interest from nutritionists, pharmacologists and the general public (Zhong, Khan \& Shahidi 2007). These marine invertebrates possess a high number of 
unique biological and pharmacological activities, including anticoagulant, anti-inflammatory, antimicrobial, antioxidant, antitumor and wound healing (Bordbar, Anwar \& Saari 2011). Moreover, from a nutritional point of view, holothurians are an ideal tonic food due to their high protein content and low fat. It also contains the amino acids and trace elements essential for keeping human health (Chen 2003).

To our knowledge, this is the first work providing reliable data that combines both the aquaculture, the biotechnological and seafood potential of a widely distributed sea cucumber species from Portugal. This experimental work aimed to study the reproductive biology of Holothuria forskali, by monthly examination of the gonadosomatic index (GI) and histological analysis to the gonadal tubules, to analyse the potential use of this species in an aquaculture production and also evaluate the biotechnological potential, by measuring the antioxidant, antimicrobial and antitumor activities, which can be useful to the development of new drugs. Furthermore, the lipid profile was also analysed to study the benefits for human wealth by a nutritional point of view.

\section{Materials and methods}

\section{Sampling and GI}

Samples of $H$. forskali were collected from the east coast (Peniche, Portugal) monthly for 10 months, with a total of 137 individuals collected. The collection was made at low tide and samples were put in proper plastic recipients and brought to the Aquaculture Laboratory of Polytechnic Institute of Leiria. A longitudinal incision was made along the dorsal surface and the coelomic fluid and gonads were removed. Drained body weight (dwt) and gonad weight (gwt) were measured and the gonads were fixed in 10\% buffered formalin for $24 \mathrm{~h}$. The GI was calculated using the following equation (Ramofafia, Battaglene, Bell \& Byrne 2000):

$$
\mathrm{GI}=\frac{\mathrm{g}_{\mathrm{wt}}}{\mathrm{d}_{\mathrm{wt}}} \times 100
$$

\section{Macroscopic examination of the gonadal tubules and histological analyses}

The maturity stages based on macroscopic examination of the gonadal tubules included: stage I - indeterminate, stage II - growing, stage III - mature, stage IV - partly spawned and stage V - spent (Ramofafia et al. 2000). For each gonad, 10 tubules were removed and their length and diameter measured. In the histological analysis, the gonadal tubules were dehydrated and embedded in paraffin. Sections ( $8 \mu \mathrm{m}$ thick) were stained with haematoxylin and eosin. Five gametogenic stages were defined: recovery, growing, mature, partly spawned and spent, following previous works (Tuwo \& Conand 1992; Ramofafia et al. 2000; Ramofafia, Byrne \& Battaglene 2003; Shiell \& Uthicke 2006; Navarro, García - Sanz \& Tuya 2012).

\section{Preparation of the extracts}

The extracts were prepared according to the adapted method by Mayachiew and Devahastin (2008). Lyophilized holothurians were ground with a mixer grinder to make a powder. This powder was sequential extracted with 1:4 biomass:solvent ratio with methanol and dichloromethane at constant stirring for $12 \mathrm{~h}$. The solvents were evaporated in a rotary evaporator (Laborota 4000; Heidolph, Schwabach, Germany) at $40^{\circ} \mathrm{C}$ and the extracts were then solubilized in dimethyl sulfoxide (DMSO) and stored at $-20^{\circ} \mathrm{C}$ until further use.

\section{Antioxidant capacity}

\section{Total phenolic content}

Total phenolic content was determined using Folin-Ciocalteau's method, according to the adapted work of $\mathrm{Yu}$, Haley, Perret, Harris, Wilson and Qian (2002). In a microtube, it was added $790 \mu \mathrm{L}$ of distilled water, $10 \mu \mathrm{L}$ of sample and $50 \mu \mathrm{L}$ of Folin-Ciocalteu reagent. After $2 \mathrm{~min}, 150 \mu \mathrm{L}$ of sodium carbonate, $\mathrm{Na}_{2} \mathrm{CO}_{3} 20 \%(\mathrm{w} / \mathrm{v})$ was added. Tubes were then vortexed and held at room temperature for $1 \mathrm{~h}$. Absorbance of the blue-coloured solution was recorded at $755 \mathrm{~nm}$ against a blank containing water instead of the Folin-Ciocalteu reagent. Total phenolic content was calculated as gallic acid equivalents using calibration curves prepared with gallic acid standard solutions. All measurements were carried out in triplicates.

\section{2,2-diphenyl-1-picrylhydrazyl radical scavenging activity}

The 2,2-diphenyl-1-picrylhydrazyl (DPPH) free radical scavenging activity was evaluated by Duan, Zhang, Li and Wang (2006) method. A solution of DPPH $0.1 \mathrm{mM}$ in ethanol was 
prepared. Then, it was added $10 \mu \mathrm{L}$ of sample to $990 \mu \mathrm{L}$ of DPPH solution. The mixture was vortexed for $1 \mathrm{~min}$ and allowed to stand at room temperature in the dark for $30 \mathrm{~min}$. A blank was prepared by adding $10 \mu \mathrm{L}$ of extracts to $990 \mu \mathrm{L}$ of ethanol. The control was $990 \mu \mathrm{L}$ of DPPH solution with $10 \mu \mathrm{L}$ of DMSO. Changes in the absorbance were measured through spectrophotometric reading at $517 \mathrm{~nm}$. All measurements were carried out in triplicates and the radical scavenging activity was expressed as the inhibition percentage and was calculated using the following formula:

$$
\begin{aligned}
\text { \%radical scavenging }= & \frac{\mathrm{Abs}_{\text {sample }}-\mathrm{Abs}_{\text {blank }}}{A b s_{\text {control }}} \\
& \times 100
\end{aligned}
$$

Oxygen radical absorbent activity

The oxygen radical absorbent capacity assay (ORAC) method was performed as described by Dávalos, Gómez - Cordovés and Bartolome (2004) as follows: The reaction was carried out in $75 \mathrm{mM}$ phosphate buffer ( $\mathrm{pH} 7.4)$, and the final reaction mixture was $200 \mu \mathrm{L}$. Sample $(20 \mu \mathrm{L})$ and fluorescein $(120 \mu \mathrm{L}$; $70 \mathrm{nM}$, final concentration) were placed in the well of the microplate. The mixture was pre-incubated for $15 \mathrm{~min}$ at $37^{\circ} \mathrm{C}$. AAPH solution $(60 \mu \mathrm{L} ; 12 \mathrm{mM}$, final concentration) was added rapidly using a multichannel pipet. The microplate was immediately placed in the reader and the fluorescence recorded every minute for $240 \mathrm{~min}$. The microplate was automatically shaken prior each reading. A blank using phosphate buffer instead of the fluorescein and eight calibration solutions using Trolox $(1-8 \mu \mathrm{M}$, final concentration) as antioxidant were also carried out in each assay. All the reaction mixtures were prepared in duplicate, and at least three independent assays were performed for each sample.

Antioxidant curves (fluorescence vs. time) were first normalized to the curve of the blank corresponding to the same assay by multiplying original data by the factor fluorescence $e_{\text {blank,t=0}} /$ fluorescence $_{\text {sample }, \mathrm{t}=0}$. From the normalized curves, the area under the fluorescence decay curve (AUC) was calculated as:

$$
\mathrm{AUC}=1+\sum_{i=1}^{i=80} f_{i} / f_{0}
$$

where $f_{0}$ is the initial fluorescence reading at $0 \mathrm{~min}$ and $f_{i}$ is the fluorescence reading at time $i$. The net
AUC corresponding to a sample was calculated by subtracting the AUC corresponding to the blank. Regression equations between net AUC and antioxidant concentration were calculated for all the samples. ORAC values were expressed as Trolox equivalents by using the standard curve calculated for each assay. Final results were in $\mu$ mol of Trolox equivalent (TE)/g of extract.

\section{Antimicrobial activity}

The antimicrobial activity of $H$. forskali extracts was evaluated against seven microorganisms: Escherichia coli (ATCC 25922 and ATCC 10536), Pseudomonas aeruginosa (ATCC 27853), Bacillus subtilis (ATCC 6633) and Salmonella enteritidis (ATCC 13076) cultured at $37^{\circ} \mathrm{C}$ in Luria - broth; Staphylococcus aureus (ATCC 25923) cultured at $37^{\circ} \mathrm{C}$ in Trypticase Soy Yeast Extract medium and Saccharomyces cerevisiae (ATCC 9763) and Candida albicans (ATCC 10231) cultured in Yeast Extract Peptone Dextrose medium at 30 and $37^{\circ} \mathrm{C}$ respectively. All mediums were obtained from Merck (Darmstadt, Germany).

The assays were performed in 96 well plates, where it was added $193 \mu \mathrm{L}$ of medium, $5 \mu \mathrm{L}$ of microorganism inoculum and $2 \mu \mathrm{L}$ of test samples per well and then incubated. Chloramphenicol (1 $\left.\mathrm{mg} \mathrm{mL}^{-1}\right)$ and amphotericin B $\left(300 \mu \mathrm{g} \mathrm{mL}^{-1}\right.$; Sigma Aldrich, Oakville, Canada) were used as positive controls and a blank for each sample was prepared. All samples were sterile filtered and the assays were performed in eight independent experiments under sterile conditions.

The ability of the extracts to inhibit the microorganism's growth was evaluated through spectrophotometric analysis at $600 \mathrm{~nm}$. The results were expressed in percentage of control by the following equation:

$$
\begin{aligned}
\text { Growth reduction }(\%)= & \frac{\mathrm{Abs}_{\text {sample }}-\mathrm{Abs}_{\text {white }}}{A \mathrm{As}_{\text {control }}} \\
& \times 100
\end{aligned}
$$

where $\mathrm{Abs}_{\text {sample }}$ corresponds to the absorbance of the microorganism growth in the presence of the sea cucumber extracts, $\mathrm{Abs}_{\text {white }}$ corresponds to the absorbance of the extracts in the respective medium and the $\mathrm{Abs}_{\text {control }}$ corresponds to the absorbance of the normal microorganism growth.

Fractions that showed the highest potential in reducing microorganism's growth were also 
evaluated through dose-response analysis to determine the $\mathrm{IC}_{50}$ values.

\section{Cytotoxic and anti-proliferative activities}

The cytotoxic potential (cell proliferation and viability) was tested on MCF-7 (breast carcinoma) and HepG-2 (human hepatocellular carcinoma) cells lines. Cells were cultured in RPMI 1640 medium supplemented with $10 \%$ of foetal bovine serum (FBS) and 1\% antibiotic/antimycotic for HepG-2 cell line and $10 \%$ of FBS, $1 \%$ antibiotic/antimycotic, MEM (non-essential amino acids), sodium pyruvate at $1 \mathrm{mM}$ and human insulin at $10 \mu \mathrm{g} \mathrm{mL}^{-1}$ for MCF-7 cell line. The cells lines were maintained in culture in a $\mathrm{CO}_{2}$ incubator at $5 \% \mathrm{CO}_{2}, 95 \%$ humidity and a constant temperature of $37^{\circ} \mathrm{C}$.

The cell proliferation and cell viability studies were evaluated through the method reported by Pedrosa and Soares-da-Silva (2002) and Yuan and Walsh (2006). For cells proliferation assays, after $36 \mathrm{~h}$ of the cells being seeded in 96-well plates, it was added $100 \mu \mathrm{L}$ of medium with serum and $100 \mu \mathrm{L}$ of medium without serum with the sea cucumber extracts. All fractions tested were incubated at $1 \mathrm{mg} \mathrm{mL}^{-1}$ for $24 \mathrm{~h}$. In cells viability assays, after the cells reach the total confluences, it was added $200 \mu \mathrm{L}$ of the extracts dissolved in medium without serum. All fractions were incubated at $1 \mathrm{mg} \mathrm{mL}^{-1}$ for $24 \mathrm{~h}$.

A dose-response assay $\left(\mathrm{IC}_{50}\right)$ was performed, for the fractions that showed the highest potential. The effects were revealed by the MTT and CalceinAM methods. The results were presented as percentage of control, being calculated by the following equation:

$$
\% \text { of control }=\frac{F_{\text {sample }}}{F_{\text {control }}} \times 100
$$

where $F_{\text {sample }}$ corresponds to the fluorescence/ absorbance of the sea cucumber extracts plus cells lines and $F_{\text {control }}$ corresponds to the fluorescence/ absorbance of DMSO (same \% of the extracts) plus cells lines.

\section{Quantification of total fat content and fatty acid profile}

Total fat content evaluation was followed according to the modified Bligh and Dyer (1959) method. Previously homogenized sample (10 g) was weighed and dissolved in $30 \mathrm{~mL}$ methanol:chloroform $(2: 1 \mathrm{v} / \mathrm{v})$ solution, with homogenization. Then,
$4 \mathrm{~mL}$ of $\mathrm{NaCl}, 10 \mathrm{~mL}$ ultrapure water, and $10 \mathrm{~mL}$ chloroform were added and the solution was stirred again for $5 \mathrm{~min}$ at $400 \mathrm{rpm}$. The mixture was kept in an ultrasonic bath $(45 \mathrm{kHz}, 130 \mathrm{~W})$ at $25^{\circ} \mathrm{C}$ for $10 \mathrm{~min}$. The solution was then filtered under vacuum and the filtrate was transferred to a separating funnel, vigorously agitated and allowed to settle for phase separation. The organic bottom layer was collected and dried through an anhydrous sodium sulphate column. The filtrate was then recovered into a vial (previously weighed), and the solvent was evaporated at $40^{\circ} \mathrm{C}$. After that, the vial was weighed and the total fat content was calculated according to the following equation:

$$
\text { Total fat content }(\%)=\frac{F_{w}-I_{w}}{S_{w}} \times 100
$$

where $I_{w}$ is the initial weight of the vial $(\mathrm{g}), F_{w}$ is the final weight of the vial $(\mathrm{g})$ and $S_{w}$ is the sample weight $(\mathrm{g})$.

The fatty acid profile was performed by adapting the method of Lepage and Roy (1986). Crude fat (300 mg) was dissolved in $5 \mathrm{~mL}$ acetyl chloride: methanol $(1: 19 \mathrm{v} / \mathrm{v})$ and heated in a water bath at $80^{\circ} \mathrm{C}$ for $1 \mathrm{~h}$. Then, $1 \mathrm{~mL}$ ultrapure water and $2 \mathrm{~mL} \mathrm{n}$-heptane were added and the solution was vortex-stirred for $1 \mathrm{~min}$ followed by centrifugation at $1500 \mathrm{~g}$ for $5 \mathrm{~min}$. The organic upper phase was recovered and analysed by GC A Finnigan Ultra Trace gas chromatograph equipped with a Thermo TR-FAME capillary column, an auto sampler AS 3000, and a flame ionization detector, to detect the fatty acid methyl esters.

\section{Statistical analysis}

A chi-squared test was held to evaluate the differences in relation to the unit. Also, a two-way ANovA, followed by a Bonferroni multiple comparation test, was performed on the GI and weight (gutted). Antimicrobial and antitumor tests were analysed by a one-way ANova, followed by a Dunnett test (Zar 2009). The results were considered statistically significant at 5\%, using IBM SPSS Statistics 20 software.

\section{Results}

\section{Population characteristics}

A total of $137 \mathrm{H}$. forskali were examined during the 10-month trial. These consisted of 35 males, 
56 females and 46 individuals lacking gonad (during the experimental trial it was never observed ejected organs due to handling procedure. The animals whose gonads were absent did not lose it during the sampling procedure). The sex ratio differ significantly from the unity $\left(\chi_{(1)}^{2}=4.85 ; P<0.05\right)$. The gutted body weights of individuals varied between 40 and $80 \mathrm{~g}$ for males, 50-120 g for females and 37-80 g for individuals lacking gonad.

\section{Gonadosomatic index}

The gonad maturation pattern (Fig. 1a) over the months showed two maximum values in November and February for both sexes (and for females, it is also present a third peak in March). Overall, the GI of this species was characterized by an increasing in the GI values from September to November (reaching a peak), followed by a steady decrease till January and a maximum increase in February, followed by a decrease and slightly increase in the pre - summer and summer months (May to June). The GI values did not showed great fluctuations between sexes, suggesting that spawning pattern may be synchronous among sexes. The maximum GI values obtained were $10.17 \%$ (November), $11.72 \%$
(February) and $13.16 \%$ (March) for females and $7.46 \%$ (November) and $14.73 \%$ (February) for males. No significant differences were detected between the GI values of both sexes $\left(F_{(1,85)}=0.038\right.$; $P>0.05)$ and months $\left(F_{(2,85)}=1.001 ; P>0.05\right)$, nor was there a significant interaction between sexes and months $\left(F_{(2,85)}=1.877 ; P>0.05\right)$.

The gutted weight (Fig. 1b) did not showed great fluctuations over the months and in general, individuals lacking gonad weighted less than the sexed individuals. Significant differences were detected between sexes $\left(F_{(1,84)}=6.518 ; P<0.05\right)$ and months $\left(F_{(2,84)}=13.046 ; P<0.05\right)$.

\section{Gonad morphology}

Holothuria forskali gonads consisted of a single structure with a numerous branched tubules arising from the gonad basis attached to the anterior body wall. The gonoduct opened externally at the gonopore, dorsally above the mouth. The five stages of gonad development, based on tubule size and appearance, are detailed in Table 1.

Overall, the gonad growth involved the formation of new tubules arising from the gonad basis, with subsequent increase in tubule length and diameter. Throughout the entire experimental
Figure 1 (a) Monthly variation in the GI values of Holothuria forskali (mean GI values per month \pm standard deviation of the mean). (b) Monthly variation in the gutted weight values of Holothuria forskali (mean gutted weight per month \pm standard deviation of the mean. Bars are standard deviation of the mean).
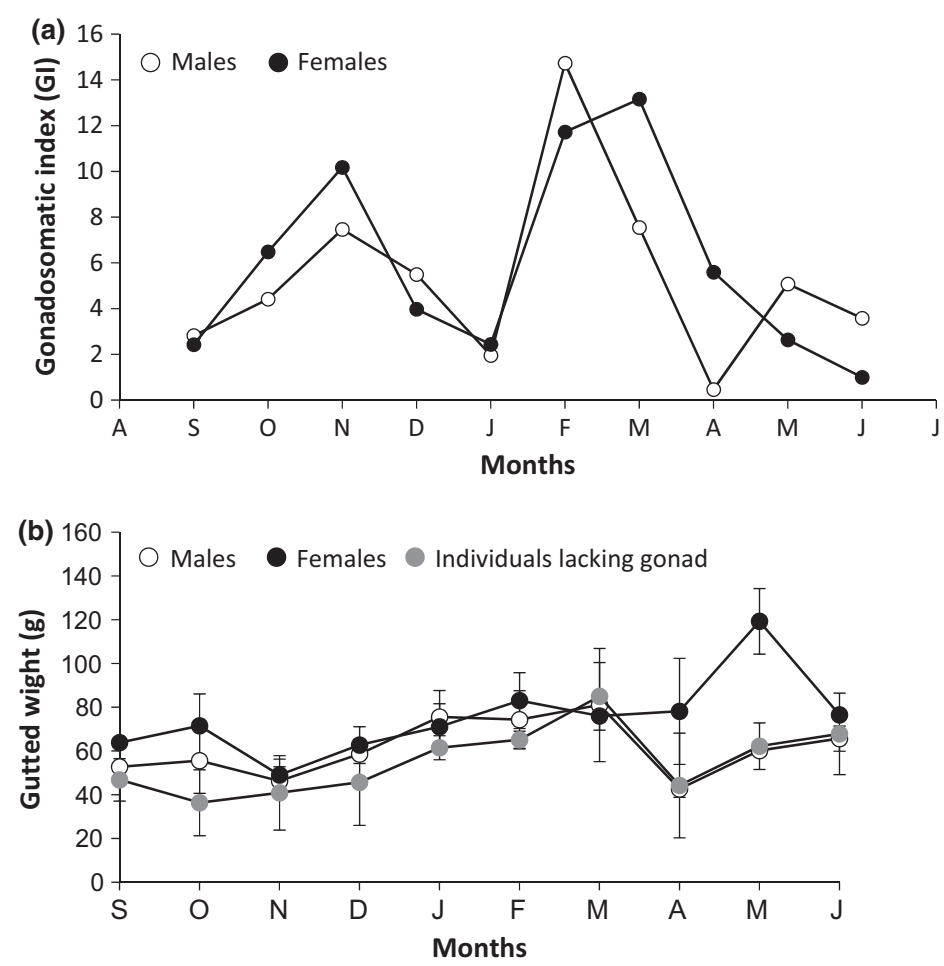
Table 1 Holothuria forskali. Five maturity stages in the reproductive cycle, based on gonad tubules morphology $(n=91)$

\begin{tabular}{|c|c|c|c|c|c|c|}
\hline \multirow{2}{*}{$\begin{array}{l}\text { Maturity } \\
\text { stage, sex }\end{array}$} & \multirow{2}{*}{$\begin{array}{l}\text { Gonad } \\
\text { wt (g) }\end{array}$} & \multicolumn{5}{|l|}{ Tubule } \\
\hline & & Length (mm) & Diameter (mm) & Branching & Condition & Colour \\
\hline \multicolumn{7}{|l|}{ I } \\
\hline Indeterminate & $\begin{array}{l}\text { Not } \\
\text { identified }\end{array}$ & & & & & \\
\hline \multicolumn{7}{|l|}{ II } \\
\hline Female & $1.3-6.5$ & $42.3-50.9$ & $1-2.1$ & $1-3$ & $\begin{array}{l}\text { Growing oocytes } \\
(61.2-80.6 \mu \mathrm{m}) \\
\text { Developing sperm }\end{array}$ & Orange \\
\hline Male & $1.1-5.9$ & $51-73.3$ & $0.7-1.6$ & $1-3$ & & Pink \\
\hline \multicolumn{7}{|l|}{ III } \\
\hline Female & $4-16.3$ & $62-105.7$ & $2-3.96$ & $1-4$ & $\begin{array}{l}\text { Oocytes visible through } \\
\text { tubule wall }(112-129.4 \mu \mathrm{m})\end{array}$ & Bright orange \\
\hline Male & $5-13.8$ & $82.6-110$ & $1.6-2.3$ & $1-4$ & Tubules packed with sperm & Salmon \\
\hline \multicolumn{7}{|l|}{ IV } \\
\hline Female & $3.1-5.7$ & $41.8-96$ & $2.1-2.8$ & $1-4$ & $\begin{array}{l}\text { Reduced tubules, relict } \\
\text { oocytes present, visible } \\
\text { empty lumen }\end{array}$ & Bright orange \\
\hline Male & $2.2-3.9$ & $28-81.8$ & $2-2.5$ & $1-4$ & $\begin{array}{l}\text { Unspawned tubules with } \\
\text { residual spermatozoa }\end{array}$ & Pink \\
\hline \multicolumn{7}{|l|}{ V } \\
\hline Female & $0.7-2.1$ & $14-34.6$ & $0.2-1$ & $1-4$ & $\begin{array}{l}\text { Tubules shrunken and } \\
\text { wrinkled in size. Relict } \\
\text { oocytes }\end{array}$ & $\begin{array}{l}\text { Orange } \\
\text { (transparent) }\end{array}$ \\
\hline Male & $0.1-1.5$ & $22.7-72$ & $0.2-0.3$ & $1-4$ & Relict sperm presented & $\begin{array}{l}\text { Pink } \\
\text { (transparent) }\end{array}$ \\
\hline
\end{tabular}

period, it was never observed the stage I (indeterminate). In stage II (growing), both females and males could be identified by the presence of developing oocytes and sperm. As the gonads approached maturity, the sex could also be determined by the colour of the gonads. For females the tubules colours were orange. For males growing testes appeared bright pink colour approximately salmon and tubules had a uniform appearance. When mature (stage III), tubules were packed with spermatozoa. Mature ovaries of females were bright orange in colour and the tubules had a transparent thin tubule walls through which oocytes were visible.

Tubule length was a good indicator of reproductive maturity, with generally the males having the longest tubules length than the females (Fig. 2). Through the spawning season, the simultaneous presence of both spawned and unspawned tubules indicated that partial spawning (stage IV) could be a characteristic of this species. Spent gonad tubules (stage V) were wrinkled and greatly reduced in size.

It was also analysed the frequency of gonad maturity stages as you can see in Figures 3 and 4 for females and males respectively. During the trial period it was observed more than one stage of gonads' maturation for some months. However, for females (Fig. 3) in September only specimens with gonads on stage II (growth) were observed. In November, February and March, the females collected had mature gonads (stage III). Finally, in June, only female's spent tubules (stage V) were present. Regarding males (Fig. 4), again in September it was only obtained individuals with the

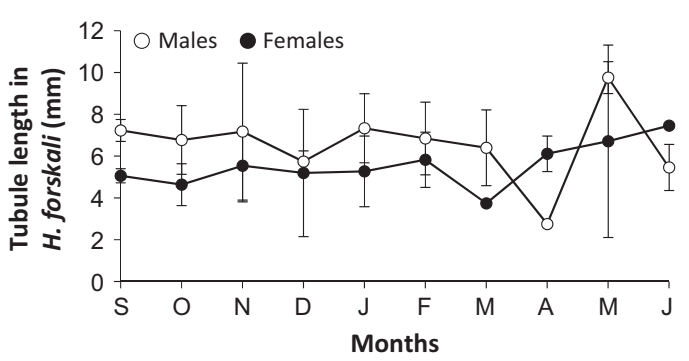

Figure 2 Monthly variation in tubule length of Holothuria forskali (mean tubule length per month \pm standard deviation of the mean. Bars are standard deviation of the mean). 
Figure 3 Frequency of gonad maturity stages of Holothuria forskali females specimens determined by the physical characteristics of large tubules $(n=56)$.
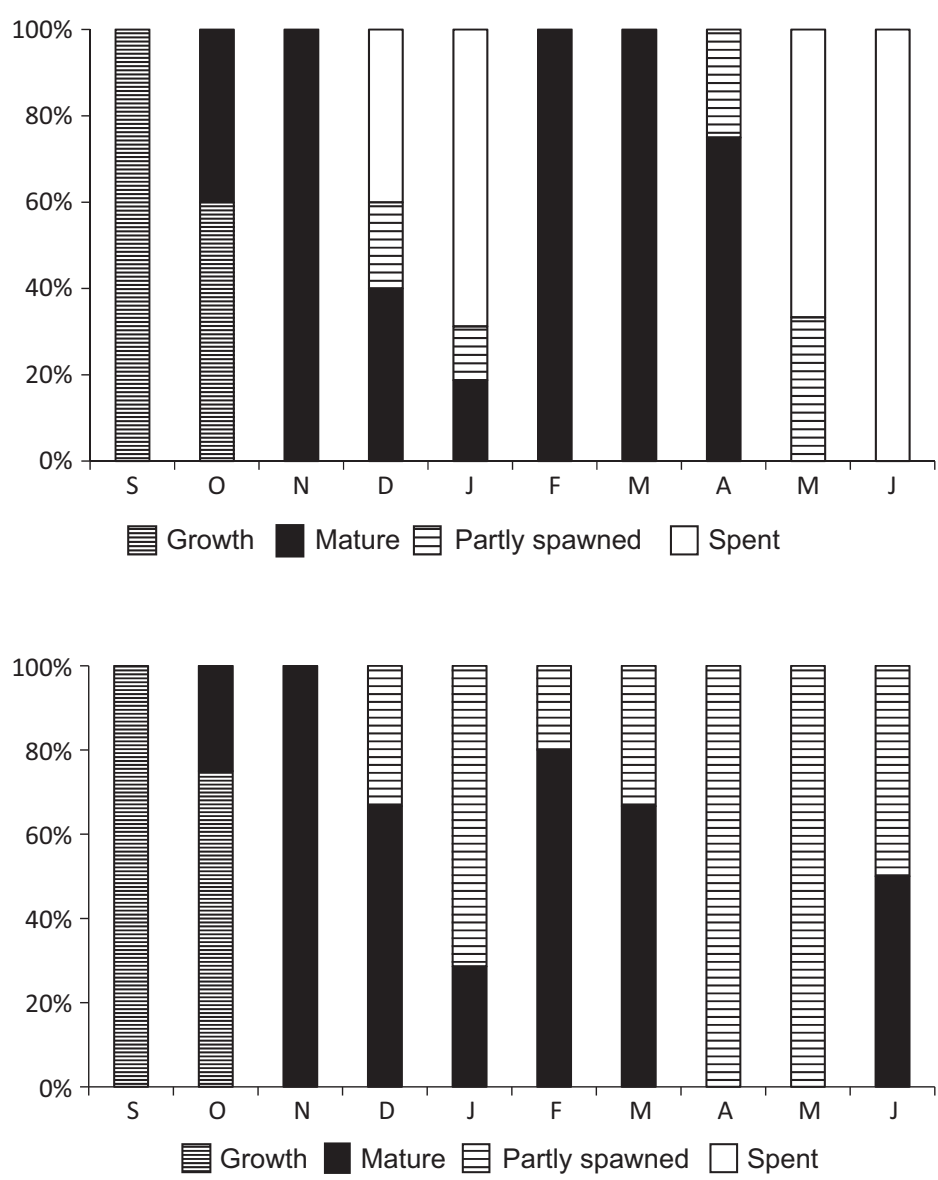

Figure 4 Frequency of gonad maturity stages of Holothuria forskali males specimens determined by the physical characteristics of large tubules $(n=35)$. description of the histological features of each gametogenic stage is detailed below.

Females

Stage II: growing. The growing stage (Fig. 5A) was characterized by active vitellogenesis. Early and mid-vitellogenic oocytes were present. These oocytes had a distinct germinal vesicle. Vitellogenic oocytes were surrounded by follicle cells throughout development.

Stage III: mature. Mature ovaries were densely packed (Fig. 5B). The oocytes remained within their follicle and with the germinal vesicle. An increase in oocyte diameter occurs and it is possible to visualize a well-defined nucleus.

Stage IV: partly spawned. It was observed that not all ovarian tubules released gametes during spawning. Partly spawned ovaries contained both spawned and unspawned tubules (Fig. 5C). Partly 

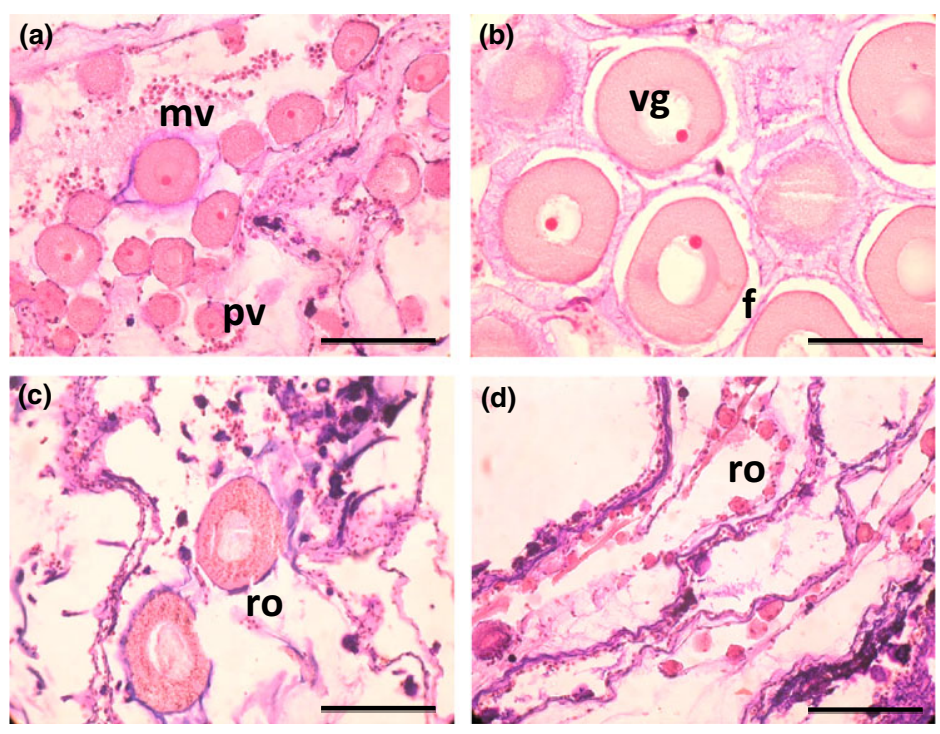

Figure 5 Oogenesis. (a) Growing ovaries, with oocytes in pre-vitellogenic (pv) and mid-vitellogenic (mv) stage. (b) Mature ovaries with oocytes enclosed with within their follicle (f) and germinal vesicle (gv). (c) Partly spawned ovaries, with the presence of mature unspawned oocytes, relict oocytes (ro). (d) Spent ovaries with intensive shrinkage of the tubules occurred and a few relict oocytes persisted (ro); scale bars in $100 \mu \mathrm{m}$. spawned tubules had a reduced diameter and a wrinkled appearance.

Stage $V$ : spent. Spent ovaries were wrinkled and shrunken, with the presence of relict oocytes in the lumen (Fig. 5D), the gonad wall was thick.

Males

Stage II: growing. A striking feature of growing testes was the presence of numerous infolds of the germinal epithelium, which extent into the lumen (Fig. 6A). These infolds were lined by a dense layer of spermatocytes organized in short columns. It was observed late growing-stage testes due to the growing number of spermatozoa abundance in the lumen.

Stage III: mature. The infolds of the germinal epithelium were reduced or absent and the lumen was packed with spermatozoa (Fig. 6B). A few spermatocytes were present along the germinal epithelium. The gonad wall was at its minimal thickness.

Stage IV: partly spawned. It was presented spermatozoa that had not been spawned. Dense aggregation of spermatozoa and phagocytes were present in the lumen (Fig. 6C).

Stage V: spent. Spent tubules were shrunken and generally had an empty lumen, except for a few relict spermatozoa (Fig. 6D).

\section{Antioxidant activity}

No significant antioxidant activity was detected in the three methods under study for the methanolic and dichloromethane fractions of $H$. forskali.

\section{Antimicrobial activity}

To evaluate the antimicrobial potential of $H$. forskali, the methanolic and dichloromethane fractions were tested against seven microorganisms and the positive results are summarized in Figures 8 and 9. The dichloromethane fraction presented an inhibitory effect of $51.85 \pm 0.69 \%$ against S. aureus. Statistically significant differences were found in relation to the control group in both organic fractions $\left(F_{(2,17)}=5.97, \quad P<0.05\right)$ (Fig. 7).

Regarding the antifungal potential, no activity was found against S. cerevisiae, however, the methanolic fraction presented the highest activity against $C$. albicans with an inhibitory effect of $85.32 \pm 0.64 \%$ (Fig. 8). Statistically significant differences was observed, in the methanolic fraction, relative to the control group $\left(F_{(2,17)}=7.39 ; P<0.05\right)$. No statistically significant differences were observed in the dichloromethane fraction.

The dose-response effect of $H$. forskali was evaluated in the reduction in $C$. albicans growth. The $\mathrm{IC}_{50}$ value obtained was $233.2 \mu \mathrm{g} \mathrm{mL}^{-1} \quad$ (168.2$323.4 \mu \mathrm{g} \mathrm{mL}^{-1}$ ), with Amphotericin B (positive control) $\mathrm{IC}_{50}=119.3 \mu \mathrm{g} \mathrm{mL}^{-1}\left(89.8-158.5 \mu \mathrm{g} \mathrm{mL}^{-1}\right.$; Fig. 9). 

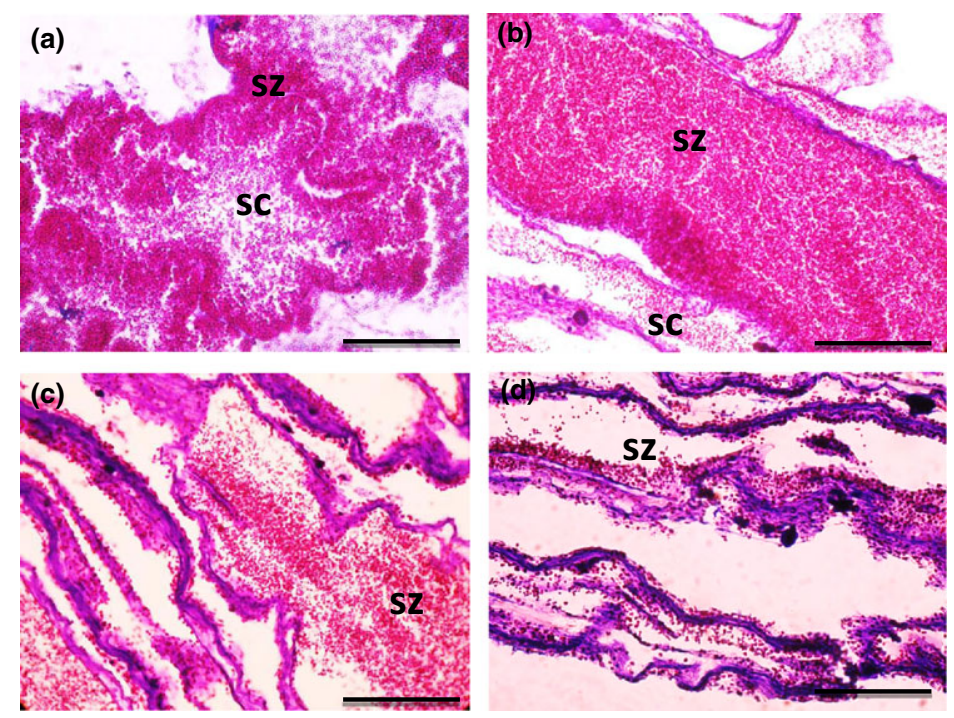

Figure 6 Spermatogenesis. (a) Growing testes, with developing spermatocytes (sc) and spermatozoa (sz) began to fill lumen as growth progress. (b) Mature testes with spermatocytes (sc) persisting along gonad wall and a fully spermatozoa (sz) accumulation. (c) Partly spawned testes, with spermatozoa (sz) in the lumen. (d) Spent testes with residual spermatozoa (sz) or empty lumen; scale bars in $100 \mu \mathrm{m}$.

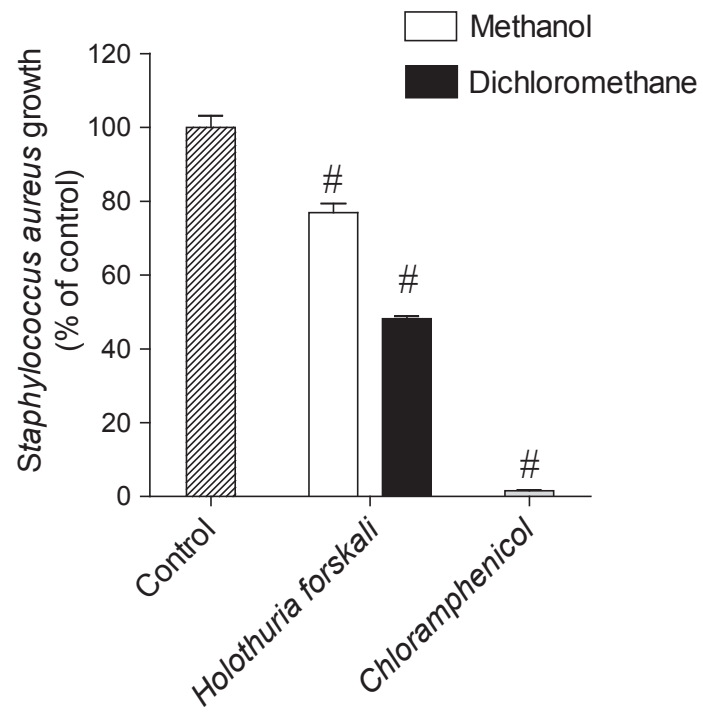

Figure 7 Holothuria forskali's effects $\left(1 \mathrm{mg} \mathrm{mL}^{-1}\right)$ in the growth of $S$. aureus (mean percentage of growth reduction compared to the control group \pm standard error of the mean). \# represents the statistical differences at a significant level of $5 \%$. Chloroamphenicol ( $\left.1 \mathrm{mg} \mathrm{mL}^{-1}\right)$.

Cytotoxic activity in MCF-7 and HepG-2 cells line

Cytotoxicity effects of sea cucumber extracts in the cells line MCF-7 and HepG-2

The cell viability tests showed that both in MCF-7 (Fig. 10A) and HepG-2 (Fig. 10B) cells line,

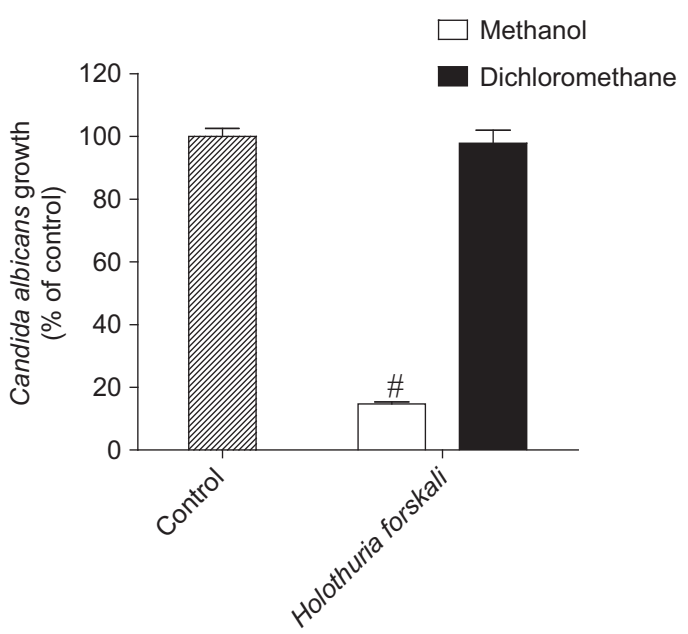

Figure 8 Holothuria forskali's effects $\left(1 \mathrm{mg} \mathrm{mL}^{-1}\right)$ in the growth of Candida albicans (mean percentage of growth reduction compared to the control group \pm standard error of the mean). \# represents the statistical differences at a significant level of $5 \%$.

H. forskali, in the methanolic fraction, at $1 \mathrm{mg} \mathrm{mL} \mathrm{m}^{-1}$, showed a high potential in the reduction in cell viability, compared to the control group. The results revealed by the MTT method presented the highest percentage of cell viability reduction in both cells lines with $100 \%$ of reduction in MCF-7 (0.00 $\pm 0.32 \%$ viable cells $)$ and $91.3 \%$ in HepG-2 $(8.70 \pm 2.44 \%$ viable cells $)$. 


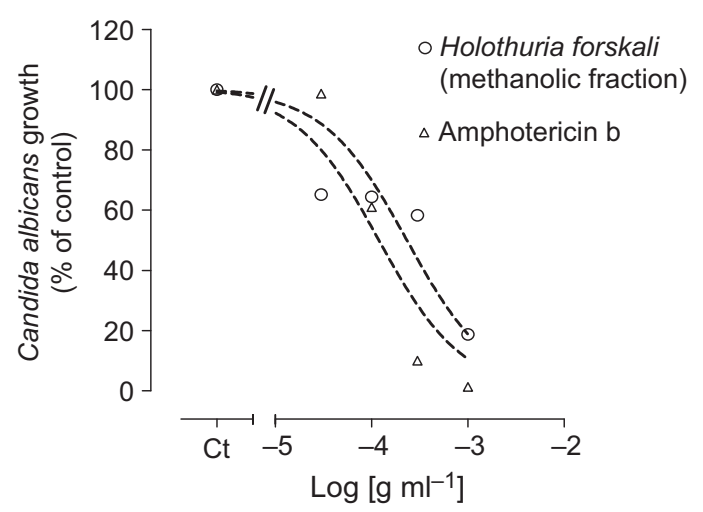

Figure 9 Holothuria forskali's dose-response analysis (30-1000 $\left.\mu \mathrm{g} \mathrm{mL}^{-1}\right)$ to define $\mathrm{IC}_{50}$ values. Amphotericin $\mathrm{B}\left(3-100 \mu \mathrm{g} \mathrm{mL}^{-1}\right)$. The symbols represents the average of 3 independent experiments.
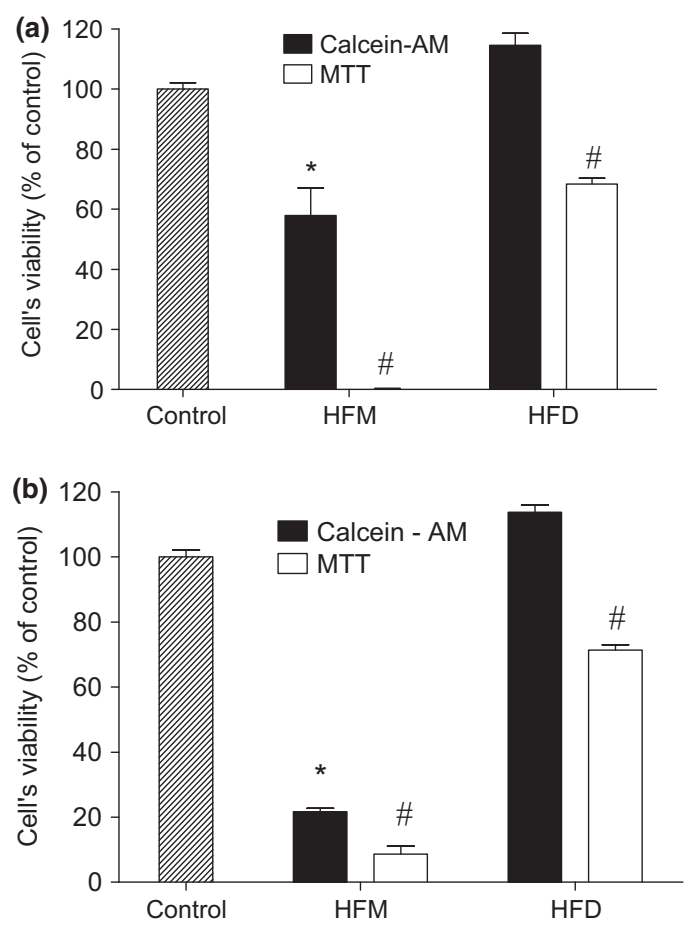

Figure 10 Holothuria forskali's effects $\left(1 \mathrm{mg} \mathrm{mL}^{-1}\right)$ on cells viability for MCF-7 (A) and HepG-2 cells line (B) (\% control), after $24 \mathrm{~h}$ of incubation. Values are mean \pm standard error of mean $(n=8)$. ${ }^{\#} P<0.05$ represents statistically significant differences in MTT method relative to the control, $* P<0.05$ represents statistically significant differences in Calcein-AM method, compared to the control. C - Control group; HFM - Holothuria forskali, methanol fraction; HFD Holothuria forskali, dichloromethane fraction.
Statistically significant differences were observed in MCF-7 cell line, except for the dichloromethane fraction, in the Calcein-AM method $\left(F_{(2,31)}=22.29 ; \quad P<0.05\right.$ for MTT method and $F_{(2,30)}=33.01 ; P<0.05$ for the Calcein-AM).

Regarding the cell line HepG-2, statistically significant differences were observed relative to the control group, except for the dichloromethane fraction in the Calcein-AM method $\left(F_{(2,27)}=1.29 ; P<0.05\right.$ for the MTT method and $F_{(2,27)}=5.13 ; P<0.05$ for the Calcein-AM method).

Table 2 presents the $\mathrm{IC}_{50}$ values for both cells lines in both methods, where the lowest values were obtained by the MTT method.

Effect of sea cucumber extracts on the inhibition of cell proliferation in MCF-7 and HepG-2 cells line

The cell proliferation assays demonstrated that both in MCF-7 (Fig. 11A) and HepG-2 (Fig. 11B) cells line, H. forskali, in the methanolic fraction, presented the highest potential $\left(1 \mathrm{mg} \mathrm{mL}^{-1}\right)$ in the inhibition of cell proliferation, after $24 \mathrm{~h}$ of incubation, when revealed by the MTT method. In MCF-7, a total inhibition was obtained $(100 \pm 0.23 \%$ inhibition in cell proliferation) and in HepG-2 a $95.15 \pm 0.38 \%$ inhibition in cell proliferation was observed.

Statistically significant differences were observed in MCF-7 cell line except for the dichloromethane fraction of the Calcein-AM method $\left(F_{(2,31)}=28.39 ; \quad P<0.05\right.$ for MTT method and $F_{(2,31)}=69.21 ; P<0.05$ for the Calcein-AM).

Regarding HepG-2 cell line, statistically significant differences were observed relative to the control group except for the dichloromethane fraction for the Calcein-AM method $\left(F_{(2,31)}=25.62\right.$; $P<0.05$ for the MTT method and $F_{(2,31)}=28.60$; $P<0.05$ for the Calcein-AM method).

Table 3 presents the $\mathrm{IC}_{50}$ values for both cells lines in both methods, where once again the lowest values were obtained by the MTT method.

\section{Quantification of total fat content and fatty acid profile}

The total fat content for H. forskali was $4.83 \pm 2.33 \%$. Table 4 revealed the fatty acid profile with high abundance in araquidonic acid

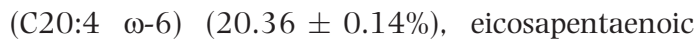
acid (C 20:5 $\omega 3$ ) (10.49 $\pm 0.21 \%$ ) and stearic acid (C18:0) (11.23 $\pm 0.16 \%)$. Concerning the amount of $\omega 3$ and $\omega 6$, the ratio was found to be 0.46 . 
Table 2 IC $_{50}$ values, in cells viability tests, for MCF7 and HepG-2 cells lines in both methods

\begin{tabular}{lll}
\hline & MCF-7 & HepG-2 \\
\hline MTT & $238.2 \mu \mathrm{g} \mathrm{mL}^{-1}(182.3-311.4)$ & $396.0 \mu \mathrm{g} \mathrm{mL}^{-1}(284.7-550.8)$ \\
Calceín-AM & $945.2 \mu \mathrm{gL}^{-1}(654.2-1366.0)$ & $855.2 \mu \mathrm{gL}^{-1}(597.4-1224.0)$ \\
\hline
\end{tabular}
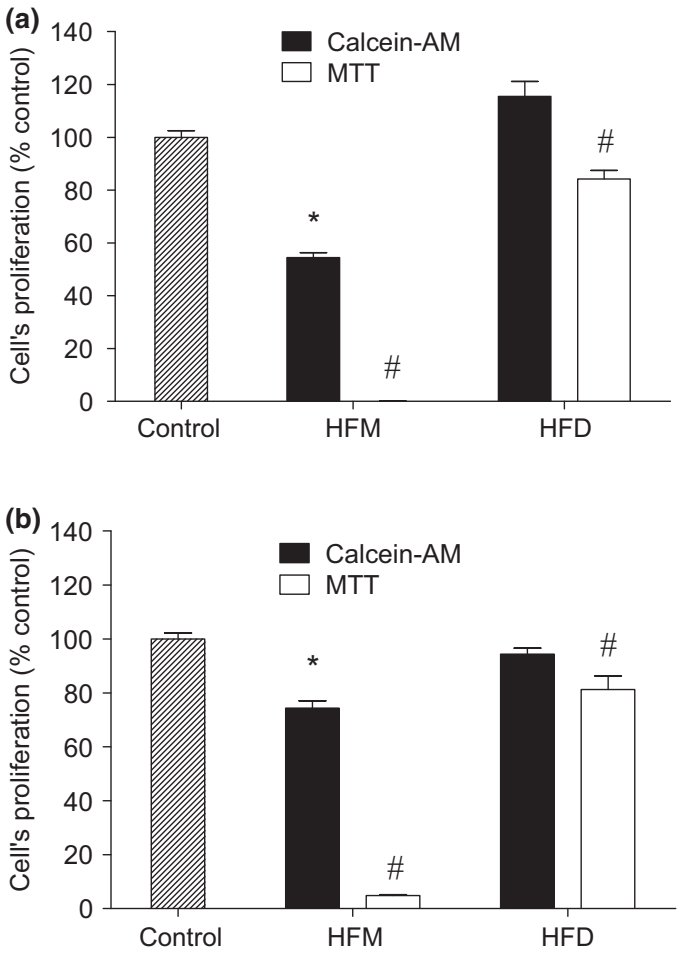

Figure 11 Holothuria forskali's effects $\left(1 \mathrm{mg} \mathrm{mL}^{-1}\right)$ on cells proliferation of MCF-7 (A) and HepG-2 cells line (B) (\% control), after $24 \mathrm{~h}$ of incubation. Values are mean \pm standard error of mean $(n=8)$. ${ }^{\#} P<0.05$ represents statistically significant differences in MTT method relative to the control, $* P<0.05$ represents statistically significant differences in Calcein-AM method, compared to the control. C - Control group; HFM - Holothuria forskali, methanol fraction; HFD Holothuria forskali, dichloromethane fraction.

\section{Discussion}

Although H. forskali has a wide geographic distribution, no aquaculture production has yet been implemented. On the other hand, some preliminary efforts are currently being made, specifically related to the need of studies about its reproductive biology, which constitute a primordial step to correctly implement an aquaculture system for this sea cucumber species. Moreover, data on its repro- ductive biology were only reported in a study by Tuwo and Conand (1992) about a specific population in France and no data, concerning its biotechnological potential and food resource, is available. As a result, any attempt to compare our results with other populations is difficult. Therefore, our data were compared with those previously reported for similar species of the Holothuria genus or other species from the Aspidochirotida order at different geographic regions (Navarro et al. 2012).

\section{Sex ratio}

The sex ratio obtained for $H$. forskali showed a significant difference in the 1:1 relation. In most holothurians from the Aspidochirotida order, this ratio often coincides with a balanced 1:1 ratio (Ramofafia, Battaglene \& Byrne 2001; Rasolofonirina, Vaitilingon, Eeckhaut \& Jangoux 2005; Asha \& Muthiah 2008). However, some species demonstrated an unbalanced ratio of $1: 2$ or $2: 3$, due to fishing pressures that affects the population of a given area (Shiell \& Uthicke 2006; Muthiga, Kawaka \& Ndirangu 2009). In this study, the sample location is not considered a local with high fishing activity. However, it is a place subject to strong sea waves, which is considered to be another major factor affecting the balanced sex ratio due to strong sea waves often promote species' evisceration as a stress response.

\section{GI and gutted weight}

According to Smiley, McEuen, Chafee and Krishan (1991), species from temperate regions usually have an annual reproductive cycle and a consequence spawning event in spring-summer (McEuen \& Chia 1991; Hamel, Himmelman \& Dufresne 1993). On the other hand, tropical sea cucumbers species have long reproductive cycles throughout the year (Conand 1993). The gonads maturation is controlled by endogenous factors but is deeply affected by exogenous parameters, particularly temperature and water disturbance (Morgan 2000; Ramofafia et al. 2003; Shiell \& Uthicke 
Table 3 IC $_{50}$ values, in cells proliferation tests, for MCF7 and HepG-2 cells lines in both methods

\begin{tabular}{lcc}
\hline & MCF-7 & HepG-2 \\
\hline MTT & $260.3 \mu \mathrm{g} \mathrm{mL}^{-1}(186.7-362.9)$ & $218.7 \mu \mathrm{g} \mathrm{mL}^{-1}(149.4-320.0)$ \\
Calceín-AM & $1445.0 \mu \mathrm{gL}^{-1}(1011.0-2066.0)$ & $1462.0 \mu \mathrm{gL}^{-1}(1002.0-2133.0)$ \\
\hline
\end{tabular}

Table 4 Fatty acid profile of Holothuria forskali by mean of fatty acid \pm standard deviation $(\mathrm{n}=3)$

\begin{tabular}{lc}
\hline Fatty acid & Holothuria forskali \\
\hline$\sum$ SFA $^{*}$ & $22.95 \pm 0.84$ \\
C $12: 0$ & $0.56 \pm 0.00$ \\
C $14: 0$ & $1.20 \pm 0.17$ \\
C $16: 0$ & $9.96 \pm 0.52$ \\
C 18:0 & $11.23 \pm 0.16$ \\
$\sum$ MUFA & $6.44 \pm 0.63$ \\
C 18:1 $\omega 7$ & $3.83 \pm 0.21$ \\
C 18:1 $\omega 9$ & $2.61 \pm 0.42$ \\
$\sum$ PUFA & $43.64 \pm 0.80$ \\
C $16: 3$ & $4.18 \pm 0.03$ \\
C $18: 3 \omega 3$ & $0.98 \pm 0.09$ \\
C 20:2 $\omega 6$ & $6.62 \pm 0.24$ \\
C 20:4 $\omega 6$ & $20.36 \pm 0.14$ \\
C $20: 5 \omega 3$ & $10.49 \pm 0.21$ \\
C $22: 6 \omega 3$ & $1.01 \pm 0.09$ \\
$\omega 3 / \omega 6$ & 0.46 \\
\hline
\end{tabular}

*Saturated.

$\dagger$ Monounsaturated.

\$Polyunsaturated.

2006; Muthiga et al. 2009; Navarro et al. 2012). According to official data of the Portuguese Institute of Ocean and Atmosphere (IPMA), the period of November 2012 coincided with strong sea waves, however, not being a period with a surface water temperature abnormal for the season. However, concerning sea wave's disturbance, it is known that this profoundly affects the organisms that inhabit the intertidal region, often causing evisceration and other stressful behaviours (Morgan 2000).

According to Tuwo and Conand (1992), H. forskali presents a long period of gonad maturation, from October to February, spawning only in the earlier spring, which corresponds to a period of calm waters rich in nutrients. As a consequence, the peak observed in November could have been caused by stressful behaviours, as a consequence of sea wave disturbance, with gonad being released, and not a typical spawning period. The peak of February showed the longest gonad maturation and could be related to individuals who were probably less exposed to strong sea waves, and therefore not eviscerate themselves.
Gutted body weights of both sexes demonstrated slightly differences between males and females. In general, females were heavier than males due to the higher fecundity rates, requiring greater nutrient storage. In November, both sexes presented low weight values possible due to evisceration phenomena. Individuals lacking gonad's weights were generally slightly lighter than sexed individuals, which demonstrates the gonad importance in establishing an individual weight (Morgan 2000; Ramofafia et al. 2000, 2003; Asha \& Muthiah 2008; Navarro et al. 2012).

\section{Macroscopic analysis of gonadal tubules and Histological analysis}

The monthly assessment of the gonadal tubules length showed some discrepancies between sexes. Overall, the males gonadal tubules length was largest than the females gonadal tubules. It is a common feature of sea cucumbers, females having higher number of tubules (given its highest reproductive output) than males (Shiell \& Uthicke 2006; Toral - Granda \& Martínez 2007). However, as described for Holothuria fuscogilva, Holothuria nobilis, Holothuria scabra and Holothuria atra, the males' gonadal tubules are slightly longer in length (Conand 1993).

The histological analysis performed revealed that the range of oocytes diameter in stage III (mature) was 112-129.4 $\mu \mathrm{m}$. These results are lower than the common range of other species of the Aspidochirotida order, corresponding to 150$210 \mu \mathrm{m}$ (Conand 1993). However, the results are consistent with the observed for $H$. forskali in Tuwo and Conand (1992) study, where in stage III, the oocyte diameter was 90-120 $\mu \mathrm{m}$. In stage IV, it was presented residual mature oocytes as well as in stage $\mathrm{V}$, trace oocytes were observed. These findings could indicate that spawning in this temperate species is not complete and throughout the year, it can be found oocytes in different stages of development, as observed for other tropical sea cucumbers (Ramofafia et al. 2000, 2003; Navarro et al. 2012). Concerning spermatogenesis develop- 
ment, it was possible to distinguish spermatocytes in males' gonadal tubules as they were superior in size than the spermatozoa (Costelloe 1985).

\section{Antimicrobial potential}

Microorganisms are the cause of many diseases that affect various species. On the other hand, marine invertebrates have developed highly efficient immune systems for the detection and elimination of invaders, which involves the presence of phagocytes, including phagocytosis of foreign material. It also includes the encapsulation of invading substances and the consequent degradation by hydrolytic enzymes present in cells (Beauregard, Truong, Zhang, Lin \& Beck 2001). The results achieved in this study are consistent with a study by Jawahar, Nagarajan and Shanmugam (2002), in which only tropical species Actinopyga echinites, Actinopyga miliaris, Holothuria atra and Holothuria scabra showed sensitivity (reduced growth) to Aeromonas hydrophila, Enterococcus sp., Klebsiella pneumoniae, S. aureus amoung other microorganisms. Several authors have reported that the antibacterial activity is generally more common in gram-positive bacteria (Staphylococcus aureus and Bacillus subtilis) than in gram-negative bacteria (E. coli, Pseudomonas aeruginosa and Salmonella enteritiris) (Ballantine, Gerwick, Velez, Alexander \& Guevara 1987). This is may be due to the fact that gram-negative bacteria possess an outer cell membrane and periplasmic space, not present in gram-positive bacteria (Cowan 1999). In addition, the periplasmic space itself contains a series of enzymes capable of degrading a large number of molecules, therefore being a strong defense mechanism against many antibiotics (Lambert 2002; Sofidiya, Odukoya, Afolayan \& Familoni 2009).

Regarding the antifungal potential, the results obtained demonstrated high potential in the inhibition of C. albicans growth. Several authors have been demonstrating that sea cucumbers contain a variety of triterpene glycosides, also known as saponins, which are responsible for a wide spectrum of biological activities, as antifungal, antiinflammatory, cytotoxic and other properties (Chludil, Muniain, Selder \& Maier 2002; Kumar, Chaturuedi, Shukla \& Lakshmi 2007; Ismail, Lemriss, Ben Aoun, Mhadhebi, Dellai, Kacem, Boirom \& Bouraoui 2008). The high percentage of growth reduction promoted by the methanolic fraction of H. forskali, can be associated to the presence of these saponins, which has been linked in other antifungal potential studies concerning Holothuria edulis and Stichopus chloronotus for C. albicans (Hing, Kaswandi, Azraul - Mumtazah, Hamidah, Shalan, Normalawati, Samsudin \& Ridzwan 2007), Holothuria polii for Aspergillus fumigatus and C. albicans (Ismail et al. 2008), among others.

\section{Antitumor potential}

The assessment of cell viability in MCF-7 and HepG-2 cells line showed high cytotoxic effects promoted by the methanolic extracts of $H$. forskali. The results were even more marked when the assessment was performed by the MTT method. The MTT method is characterized by a direct action on mitochondrial dehydrogenase, while the Calcein-AM method translate into a direct action at the cytoplasm (Rotter, Thompson, Clarkin \& Owen 1993; Castell \& Gómez - Lechón 1997; Hayes 1997). Saponins or in the case of sea cucumbers, holothurins and even more precisely holothurins A, B, C and D and desholothurins A from $H$. forskali, were the first to be reported in the literature as possessing a great antitumor activity (Rodriguez, Castro \& Riguera 1991). According to these authors, in $\mathrm{P}_{388}$ cell line, the holothurin A presented a similar cytotoxic potential as observed in our study. Also, H. forskali possess a defensive mechanism called the Cuverian tubules which are expelled during stressful situations. A study from Van Dyck, Gerbaux and Flammang (2009) referred that the Cuverian tubules possess a higher content of saponins than the presented in the body wall. According to Bhakuni and Rawat (2005) and Sarker, Latif and Gray (2006), with the polar solvents (methanolic extract) it is possible to extract a diverse group of compounds as saponins, tannins, some alkaloids among others, so the high cytotoxic effect promoted by the methanolic fraction of $H$. forskali can be easily correlated once again by the presence of saponins both in the body wall and residual Cuverian tubules, revealed by the methanolic fraction.

Cell proliferation assays showed the same similarities to what was observed on cell viability. Once again, H. forskali in the methanolic fraction showed the highest potential in the reduction in cell proliferation in both cells line. On the other hand, $\mathrm{IC}_{50}$ values obtained in this study were higher than the same obtained in the study by Althunibat, Hashim, Haher, Daud, Ikeda and Zali 
(2009) for H. scabra, H. leucospilota and S. chloronotus, concerning cell proliferation of cervical carcinoma $\left(\mathrm{C}_{33 \mathrm{~A}}\right)$ and lung carcinoma $\left(\mathrm{A}_{549}\right)$.

\section{Quantification of total fat content and fatty acid profile}

The total fat percentage obtained for $H$. forskali was higher than for other tropical species. This could be linked to the fact that the sampling procedure took place in winter, which is usually a period of fat storage, for sea cucumbers metabolic functions, due to rough sea waters, where sea cucumbers tend to hide in rocks. Also, another important aspect is the gonad maturation, that requires larger fat reserves and the period of sampling coincided with the long gonad maturation period for $H$. forskali. Chang-Lee, Price and Lampila (1989) have defined a range in the percentage of total fat for sea cucumbers as $0.1-0.9 \%$.

In the study by Pereira, Valentão, Teixeira and Andrade (2013) concerning H. forskali collected in the Peniche coast, this species showed a lower content of the palmitic acid (C16:0) than the results observed in our study, as well as a lower content in araquidonic acid. These discrepancies can be due to differences in sampling seasons.

The $\omega 3 / \omega 6$ ratio is an important factor in the lipid quality (Piggott \& Tucker 1990). Several studies have shown that high values of $\omega 3 / \omega 6$ ratio have resulted in an increased protection against degenerative and cardiovascular diseases (Russo 2009; Smith, Mozaffarian \& Willett 2009). Also, it is known that the European human food products possess a $\omega 6 / \omega 3$ ratio of approximately 15 to $17 / 1$. This is due to the low consumption of seafood and increasing intake of $\omega 6$ fatty acids from vegetable oil. As a consequence, western diets are low in 13 fatty acids. For this reason, the World Health Organization currently recommends a balanced proportion for $\omega 3$ and $\omega 6$ fatty acids intake and that the $\omega 6 / \omega 3$ ratio should be no higher than 10 in the diet (Stabili, Acquaviva, Biandolino, Cavallo, De Pascali, Fanizzi, Narracci, Petrocelli \& Cecere 2012). Thus, the ratio obtained in this study is situated between this range and, it is consistent with what is reported for other tropical species.

\section{Conclusion}

In summary, this study provided valuable results concerning the potential use of $H$. forskali for an aquaculture system, its great biotechnological potential and seafood potential resource. The reproductive biology study revealed that the best period for spawning is between February and March. However, through the year it is possible to find individuals in different stages of gonad maturation. A great antifungal and cytotoxic potential was obtained, revealing possible new sources of compounds with applications for the pharmaceutical industry and finally, the quantification of total fat, fatty acid profile and $\omega-3 / \omega-6$ ratio demonstrated the nutritional benefits of this sea cucumber species for human health. Although these results are preliminary and further studies are required, this work demonstrates the great potential of a holothurian species from the Peniche coast.

\section{Acknowledgments}

We thank Professor Teresa Mouga as headmaster of the School of Tourism and Maritime Technology of Peniche, for providing the authorization and support to utilize the Laboratories and other facilities, necessary to conduct this work. We would also like to thank Tiago Simões and Rita Sousa for the valuable help in the lipid profile assays, Professor Susana Mendes for all the statistical help given to this work and Professor Susana Ferreira for providing valuable help in histological photos. Finally, we thank all those who helped during the sampling procedures.

\section{References}

Althunibat O.-Y., Hashim R.B., Haher M., Daud J.M., Ikeda M.-A. \& Zali B.I. (2009) In vitro antioxidant and antiproliferative activities of three Malaysian sea cucumber species. European Journal of Scientific Research 37, 376-387.

Asha P.S. \& Muthiah P. (2008) Reproductive biology of the commercial sea cucumber Holothuria spinifera (Echinodermata: Holothuroidea) from Tuticorin, Tamil Nadu, India. Aquaculture Int. 16, 231-242.

Ballantine D.L., Gerwick W.H., Velez S.M., Alexander E. \& Guevara P. (1987) Antibiotic activity of lipid - soluble extracts from Caribbean marine algae. Hydrobioologia 151/152, 463-469.

Battaglene S.C. (1999) Culture of tropical sea cucumbers for stock restoration and enhancement. Naga The ICLARM Quaterly 22, 4-11.

Beauregard K.A., Truong N.T., Zhang H., Lin W. \& Beck G. (2001) The detection and isolation of a novel anti- 
microbial peptide from the echinoderm, Cucumaria frondosa. Advances in Experimental Medicine and Biology 484, 55-62.

Bhakuni D.S. \& Rawat D.S. (2005) Bioactive Marine Natural Products. Springer, New York, USA.

Bligh E.G. \& Dyer W.J. (1959) A rapid method for total lipid extraction and purification. Canadian Journal of Biochemistry and Physiology 37, 911-917.

Bordbar S., Anwar F. \& Saari N. (2011) High - value components and bioactives from sea cucumbers for functional foods - a review. Marine Drugs 9, 1761-1805.

Castell J.V. \& Gómez - Lechón M.J. (1997) In vitro Methods in Pharmaceutical Research, pp. 136-151. Academic Press, California, USA.

Chang-Lee M.V., Price R.J. \& Lampila L.E. (1989) Effect of processing on proximate composition and mineral content of sea cucumbers (Parastichopus spp.). Journal of Food Science 54, 567-572.

Chen J. (2003) Overview of sea cucumber farming and sea ranching practices in China. SPC Beche-de-mer Information Bulletin 18, 16-23.

Chen J. (2004) Present status and prospects of sea cucumber industry in China. In: Advances in Sea Cucumber Aquaculture and Management. FAO, Rome, Fisheries Technical Paper (ed. by A. Lovatelli, C. Conand, S. Purcell, S. Uthicke, J.-F. Hamel \& A. Mercier), Food \& Agriculture Organization 463, 25-38.

Chludil H.D., Muniain C.C., Selder A.M. \& Maier M.S. (2002) Cytotoxic and antifungal triterpene glycosides from the Pantagonian sea cucumber, Hemoiedema spectabilis. Journal of Natural Products 65, 860-865.

Conand C. (1993) Reproductive biology of the holothurians from the major communities of the New Caledonia lagoon. Marine Biology 116, 439-450.

Conand C. (2001) Overview over the last decade of sea cucumber fisheries - what possibilities for a durable management? In: Echinoderms 2000: Proceedings of the 10th International Conference, Dunedin, New Zealand (ed. by M. Barker), pp. 339-344. AA Balkerna, Rotterdam.

Conand C. (2004) Present status of world sea cucumber resources and utilization: as international overview. In: Advances in Sea Cucumber Aquaculture and Management. FAO, Rome, Fisheries Technical Paper (ed. by A. Lovatelli, C. Conand, S. Purcell, S. Uthicke, J.-F. Hamel \& A. Mercier), Food \& Agriculture Organization 463, $13-24$.

Costelloe J. (1985) The annual reproductive cycle of the holothurian Aslia lefevrei (Dendrochirota: Echinodermata). Marine Biology 88, 155-165.

Cowan M.M. (1999) Plant products as antimicrobial agents. Clinical Microbiology Reviews 12, 564-582.

Dávalos A., Gómez - Cordovés C. \& Bartolome B. (2004) Extending applicability of the oxygen radical absorbance capacity (ORAC - fluorescein) assay. Journal of Agricultural and Food Chemistry, 52, 48-54.
Duan X.J., Zhang W.W., Li X.M. \& Wang B.G. (2006) Evaluation of antioxidant property of extract and fraction from a red algae, Polysiphonia urceolata. Food Chemistry 95, 37-43.

Ferdouse F. (2004) World markets and trade flows of sea cucumbers/bêche - de - mer. In: Advances in Sea Cucumber Aquaculture and Management. FAO Fisheries Technical Paper, 463 (ed. by A. Lovatelli, C. Conand, S. Purcell, S. Uthick, J.-F. Hamel \& A. Mercier), pp. 101-117, FAO, Rome.

Ghobadyan F., Morovvati H., Ghazvineh L. \& Tavassolpour E. (2012) An investigation of the macroscopic and microscopic characteristics of gonadal tubules in the sea cucumber Holothuria leucospilota (Persian Gulf, Iran). SPC Beche-de-mer Information Bulletin 32, 6-14.

Hamel J., Himmelman J.H. \& Dufresne L. (1993) Gametogenesis and spawning of the sea cucumber Psolus fabricii (Duben and Koren). Biology Bulletin 184, 125-143.

Hayes A.W. (1997) Principles and Methods of Toxicology (3rd edn). Raven Press, New York, USA.

Hing H.L., Kaswandi M.A., Azraul - Mumtazah R., Hamidah S.A., Shalan A.Z., Normalawati S., Samsudin M.W. \& Ridzwan B.H. (2007) Effect of methanol extracts from sea cucumber Holothuria edulis and Stichopus chloronotus on Candida albicans. Microscopy and Microanalysis 13 (Suppl. 2), 270-271.

Ismail H., Lemriss S., Ben Aoun Z., Mhadhebi L., Dellai A., Kacem Y., Boirom P. \& Bouraoui A. (2008) Antifungal activity of aqueous and methanolic extracts from the Mediterranean sea cucumber, Holothuria polii. Journal of Mycologie 18, 23-26.

Ivy G., Azari D. \& Giraspy B. (2006) Development of large scale hatchery production techniques for the commercially important sea cucumber Holothuria scabra var. versicolor (Conand, 1986) in Queensland, Australia. SPC Bêche - de - mer Information Bulletin 24, 28-34.

Jawahar A.T., Nagarajan J. \& Shanmugam S.A. (2002) Antimicrobial substances of potential biomedical importance from holothurian species. Indian Journal of Marine Sciences 31, 161-164.

Kumar R., Chaturuedi A.K., Shukla P.K. \& Lakshmi V. (2007) Antifungal activity in triterpene glycosides from the sea cucumber Actinopyga lecanora. Bioorganic and Medicinal Chemistry Letters 17, 4387-4391.

Lambert P.A. (2002) Cellular impermeability and uptake of biocides and antibiotics in gram positive bacteria and mycobacteria. Journal of Applied Microbiology, Symposium Supplement 92, 46-54.

Lepage G. \& Roy C. (1986) Direct transesterification of all classes of lipids in a one - step reaction. Journal of Lipid Research 27, 114-120.

Mayachiew P. \& Devahastin S. (2008) Antimicrobial and antioxidant activities of Indian gooseberry and galan- 
gal extracts. LWT Food Science and Technology 41, 1153-1159.

McEuen F.S. \& Chia F.S. (1991) Development and metamorphosis of two Psolid sea cucumbers, Psolus chitonoides and Psolidium bullatum, with a view of reproductive patterns in the family Psolidae (Holothuroidea: Echinodermata). Marine Biology 109, 267-279.

Morgan A.D. (2000) Aspects of the reproductive cycle of the sea cucumber Holothuria scabra (Echinodermata: Holothuroidea). Bulletin of Marine Science 66, 47-57.

Muthiga N.A., Kawaka J.A. \& Ndirangu S. (2009) The timing and reproductive output of the commercial sea cucumber Holothuria scabra on the Kenyan coast. Estuarine, coastal as Shelf Science 84, 353-360.

Navarro P.G., García - Sanz S. \& Tuya F. (2012) Reproductive biology of the sea cucumber Holothuria sanctori (Echinodermata: Holothuroidea). Scientia Marina 76, 741-752.

Nelson E.J., MacDonald B.A. \& Robison S.M.C. (2012) A review of the Northern sea cucumber Cucumaria frondosa (Gunnerus, 1767) as a potential aquaculture species. Reviews in Fisheries Science 20, 212-219.

Pedrosa R. \& Soares-da-Silva P. (2002) Oxidative and non-oxidative mechanisms of neuronal cell death and apoptosis by l-3.4-dihydroxyphenylalanine (l-DOPA) and dopamine. British Journal of Pharmacology 137, 1305-1313.

Pereira D.M., Valentão P., Teixeira N. \& Andrade P.B. (2013) Amino acids, fatty acids and sterols profile of some marine organisms from Portuguese waters. Food Chemistry 141, 2412-2417.

Piggott G.M. \& Tucker B.W. (1990) Seafood: Effects of Technology on Nutrition, pp. 221-228. Marcel Dekker, New York, USA.

Raison C.M. (2008) Advances in sea cucumber aquaculture and prospects for commercial culture of Holothuria scabra. CAB Reviews 3, 1-15.

Ramofafia C., Battaglene S.C., Bell J.D. \& Byrne M. (2000) Reproductive biology of the commercial sea cucumber Holothuria fuscogilva in the Solomon Islands. Marine Biology 136, 1045-1056.

Ramofafia C., Battaglene S.C. \& Byrne M. (2001) Reproductive biology of Actinopyga mauritiana (Echinodermata: Holothuridae) in the Solomon Islands. Journal of Marine Biology Association 81, 523-531.

Ramofafia C., Byrne M. \& Battaglene C.S. (2003) Reproduction of the commercial sea cucumber Holothuria scabra (Echinodermata: Holothuroidea) in the Solomon Islands. Marine Biology 142, 281-288.

Rasolofonirina R., Vaitilingon D., Eeckhaut I. \& Jangoux M. (2005) Reproductive cycle of edible echinoderms from the Southwestern Indian Ocean. II: the sandfish Holothuria scabra (Jaeger, 1833) Western Indian Ocean. Journal of Marine Sciences 4, 61-75.

Rodriguez J., Castro R. \& Riguera R. (1991) Holothurinosides: new antitumor non sulphated triterpene glyco- sides from the sea cucumber Holothuria forskali. Tetrahedron 47, 4753-4762.

Rotter B.A., Thompson B.K., Clarkin S. \& Owen T.C. (1993) Rapid colorimetric bioassay for screening of fusarium mycotoxins. Natural toxins 1, 303-307.

Russo G.L. (2009) Dietary n-6 and n-3 polyunsaturated fatty acids: from biochemistry to clinical implications in cardiovascular prevention. Biochemical Pharmacology 77, 937-946.

Sarker S.D., Latif Z. \& Gray A.I. (2006) Natural Product Isolation. Methods in Biotechnology (2nd edn). Human Press, NJ, USA.

Shiell G.R. \& Uthicke S. (2006) Reproduction of the commercial sea cucumber Holothuria whitmaei [Holothuroidea: Aspidochirotida] in the Indian and Pacific Ocean regions of Australia. Marine Biology 148, 973-986.

Sicuro B. \& Levine J. (2011) Sea cucumber in the Mediterranean: a potential species of aquaculture in the Mediterranean. Review in Fisheries Science 19, 299-304.

Smiley S., McEuen F.S., Chafee C. \& Krishan S. (1991) Echinodermata: Holothuroidea, In: Reproduction of Marine Invertebtates, Vol. 6 (ed. by A. Giese, J. Pearse, \& V. Pearse), pp. 663-750. Echinoderms and Lophophorates. Boxwood Press, Pacific Grove, CA, USA.

Smith L., Mozaffarian D. \& Willett W. (2009) Review of fat and fatty acid requirements and criteria for developing dietary guidelines. Annual Nutritional Metabolism 55, 44-55.

Sofidiya M.O., Odukoya O.A., Afolayan A.J. \& Familoni O.B. (2009) Phenolic contents, antioxidant and antibacterial activities of Hymenocardia acida. Natural Product Research 23, 168-177.

Stabili L., Acquaviva M.I., Biandolino F., Cavallo R.A., De Pascali S.A., Fanizzi F.P., Narracci M., Petrocelli A. \& Cecere E. (2012) The lipidic extract of the seaweed Gracilariopsis longissima (Rhodophyta, Gracilariales): a potential resource for biotechnological purposes? New Biotechnology 29, 443-450.

Toral - Granda M.V. \& Martínez P.C. (2007) Reproductive biology and population structure of the sea cucumber Isostichopus fuscus (Ludwig, 1875) (Holothuroidea) in Caamaño, Gálapagos Islands, Ecuador. Marine Biology, 151, 2091-2098.

Tuwo A. \& Conand C. (1992) Reproductive Biology of the holothurian Holothuria forskali (Echinodermata). Journal of the Marine Biology Association 72, 745-758.

Van Dyck S., Gerbaux P. \& Flammang P. (2009) Elucidation of molecular diversity and body distribution of saponins in the sea cucumber Holothuria forskali (Echinodermata) by mass spectrometry. Comparative Biochemistry and Physiology, Part B 152, 124-134.

Yu L., Haley S., Perret J., Harris M., Wilson J. \& Qian M. (2002) Free radical scavenging properties of wheat extracts. Journal of Agricultural and Food Chemistry 50, 1619-1624. 
Yu Z., Qi Z., Hu C., Liu W. \& Huang H. (2012) Effects of salinity on ingestion, oxygen consumption and ammonium excretion rates of the sea cucumber Holothuria leucospilota. Aquaculture Research 44, 1-8.

Yuan Y.V. \& Walsh N.A. (2006) Antioxidant and antiproliferative activities of extracts from a variety of edible seaweeds. Food and Chemical Toxicology $\mathbf{4 4}$, 1144-1150.
Zar J.H. (2009) Biostatistical Analysis (5th edn). Prentice Hall, NJ, USA 994pp.

Zhong Y., Khan M.A. \& Shahidi F. (2007) Compositional characteristics and antioxidant properties of fresh and processed sea cucumber (Cucumaria frondosa). Journal of Agricultural and Food Chemistry 55, 1188-1192. 